\title{
Mempersoalkan Mediasi Sebagai Upaya Penyelesaian Disharmoni Peraturan Menteri
}

\section{Problems Of Mediation As A Responsibility Completion of The Ministerial Regulation}

\author{
Rahmat Akbar \\ Sekolah Tinggi Ilmu Hukum Muhammadiyah (STIHM) Bima \\ rahmatakbar1229@gmail.com \\ Ahmad Yasin \\ Sekolah Tinggi Ilmu Hukum Muhammadiyah (STIHM) Bima \\ ahmadstih65@gmail.com
}

Abstrak: Diaturnya mediasi dalam penyelesaian disharmonisasi peraturan perundang-undangan dinilai tidak sesuai dengan prinsip hukum yang dianut di Indonesia. Mediasi biasa diterapkan dalam peneyelesaian masalah privat, namun diadopsi untuk menyelesaikan sengketa disharmonisasi norma hukum. Pilihan mediasi menuai penolakan karena dianggap tidak sesuai dengan norma yang mengatur mediasi secara umum. Tulisan ini dibuat dengan tujuan untuk mengkritisi dan memberikan saran terhadap perbaikan pengaturan mediasi. Metode penelitian yang digunakan adalah penelitian hukum normative. Dengan isu hukum bahwa terdapat ketidaksesuaian norma dan/atau prinsip hukum dengan pendekatan peraturan perundang-undangan. Hasil penelitian ini bahwa terdapat ketidak sesuaian pengunaan mediasi dalam praktik di Indonesia. Mediasi yang diterapkan dalam hukum privat dicoba untuk diadopsi dalam penyelesaian masalah regulasi, hal tersebut mendapat penolakan. Selain itu, tidak terdapat norma yang memerintahkan harmonisasi peraturan Menteri untuk diatur dalam Peraturan Menteri Hukum Dan Hak Asasi Manusia Nomor 2 Tahun 2019.

Kata Kunci: harmonisasi; mediasi; peraturan Menteri 
Abstract: The regulation of mediation in resolving disharmony of laws and regulations is not following the legal principles adhered to. Mediation is usually applied in solving personal problems but is adopted to determine the friction of legal norms. It reaps general answers because it is not following the standards speaking in mediation. What created this paper is intending to criticize and provide suggestions for improving mediation arrangements. The research method used is normative legal research. With the legal issue that there is a mismatch of traditional norms and principles with statutory and regulations. This study indicates that there is a mismatch in the use of mediation in practice in Indonesia. Mediation applied in private law is tried to be adopted to settle regulatory problems, the matter is approved. Besides, no norm orders a ministerial regulation to be regulated in the minister of law and human rights, number 2 of 2019.

Keywords: harmonization; mediation; Ministerial regulation

\section{PENDAHULUAN}

Sejak berlakunya Undang-Undang Nomor 12 Tahun 2011 Tentang Pembentukan Peraturan Perundang-Undangan, Peraturan Menteri sah menjadi bagian dari Peraturan Perundang-undangan. Sebelumnya, pada Undang-Undang Nomor 10 Tahun 2004 tentang Pembentukan Peraturan Perundang-Undangan, nomenklatur Peraturan Menteri tidak dikenal. Peraturan Menteri dikenal sebagai peraturan kebijakan yang hanya berlaku atas dasar diskresi (freis emersen) yang merupakan kebijakan pemerintah sebagai bagian daripada tugas eksekutif.

Pasal 7 UU 12 Tahun 2011 Tentang Pembentukan Peraturan Perundang-Undangan menjelaskan hierarki sebagai berikut:

a. Undang-Undang Dasar Negara Republik Indonesia Tahun 1945;

b. Ketetapan Majelis Permusyawaratan Rakyat;

c. Undang-Undang/Peraturan Pemerintah Penganti Undang-Undang;

d. Peraturan Pemerintah;

e. Peraturan Presiden;

f. Peraturan Daerah Provinsi; dan

g. Peraturan Daerah Kabupaten/Kota 
Selain hierarki sebagaimana disebutkan, terdapat pula peraturan lain yang yang tercantum dalam pasal 8 ayat $1^{1}$ (UU 12 Tahun 2011) dibentuk oleh Lembaga dan Kementerian salah satunya adalah peraturan Menteri. Peraturan Menteri tidak disebutkan secara tegas dalam hierarki, namun eksistensinya diakui. Peraturan Menteri dibentuk atas dasar perintah dari peraturan yang lebih tinggi atau berdasarkan wewenang yang dimiliki.

Salah satu yang menjadi masalah dalam Pemerintahan di Republik Indonesia adalah terjadinya hiper regulasi. ${ }^{2}$ Adanya kewenangan untuk membentuk peraturan menyebabkan lembaga yang berwenang berlombalomba membuat peraturan. Berdasarkan data yang dirilis oleh Kementerian Hukum Dan Hak Asasi Manusia, bahwa jumlah peraturan perundang-undangan di Indonesia sebanyak 39.294 . $^{3}$ Dari angka tersebut, Peraturan Menteri berjumlah 15.455. Melihat besarnya angka tersebut, Peraturan Menteri menjadi salah satu penyumbang terhadap hiper regulasi di Indonesia.

Peraturan Menteri dapat dibentuk dengan dua alasan yaitu mendapat amanat dari peraturan perundang-undangan yang lebih tinggi atau berdasarkan kewenangannya. ${ }^{4}$ Amanat tersebut dapat berupa atribusi atau delegasi yang diberikan untuk mengatur lebih lanjut ke dalam peraturan yang lebih detail. Selain itu, Menteri memiliki kewenangan untuk mengatur hal-hal yang menjadi tugas dan tanggung jawabnya sebagai bagian daripada penyelenggara pemerintahan. Di sisi lain, kewenangan tersebut melahirkan ego sektoral menyebabkan setiap kementerian membuat peraturan yang pada akhirnya produk yang dibuat tersebut berpotensi terjadinya disharmoni dan tumpang tindih.

Tidak terdapatnya lembaga yang berwenang untuk melakukan harmonisasi terhadap Peraturan Menteri menyebabkan masalah terus berlanjut. Menteri Hukum dan HAM sebagai Pembantu Presiden salah satu

\footnotetext{
1 peraturan yang ditetapkan oleh Majelis Permusyawaratan Rakyat, Dewan Perwakilan Rakyat, Dewan Perwakilan Daerah, Mahkamah Agung, Mahkamah Konstitusi, Badan Pemeriksa Keuangan, Komisi Yudisial, Bank Indonesia, Menteri, badan, lembaga, atau komisi yang setingkat yang dibentuk dengan Undang-Undang atau Pemerintah atas perintah Undang-Undang, Dewan Perwakilan Rakyat Daerah Provinsi, Gubernur, Dewan Perwakilan Rakyat Daerah Kabupaten/Kota, Bupati/Walikota, Kepala Desa atau yang setingkat.

${ }^{2}$ Hasil penelitian dari Pusat Studi Hukum dan Kebijakan (PSHK) baru-baru ini menyebutkan bahwa terjadi hiper regulasi atau penerbitan peraturan perundang-udangan yang sangat banyak di level eksekutif

https://www.kompas.com/tren/read/2019/10/16/210556065/menelaah-fenomena-hiperregulasi-apa-sebabnya?page=all diakses pada 21 Maret 2021

${ }^{3}$ https://peraturan.go.id/

4 Pasal 8 ayat (2) Peraturan Perundang-undangan sebagaimana dimaksud pada ayat (1) diakui keberadaannya dan mempunyai kekuatan hukum mengikat sepanjang diperintahkan oleh Peraturan Perundang-undangan yang lebih tinggi atau dibentuk berdasarkan kewenangan.
} 
tugasnya adalah melakukan harmonisasi peraturan perundang-undangan. Namun, Kementerian Hukum dan HAM hanya melakukan harmonisasi terbatas $^{5}$ pada beberapa Peraturan Perundang-Undangan, sedangkan Peraturan Menteri masuk pada kategori peraturan perundang-undangan lain dan diakui namun tidak masuk dalam hierarki. Bahwasanya Peraturan Menteri dibentuk oleh setiap kementerian dan ditetapkan pula oleh kementerian yang membentuknya. Di sisi lain, kementerian memiliki kepentingan akan peraturan yang dibuatnya, oleh karena itu kementerian berpotensi kehilangan obyektivitasnya dalam menilai produk yang disusun sendiri. Perlu adanya Lembaga yang dapat melakukan harmonisasi terhadap Peraturan Menteri, harmonisasi dapat dilakukan pada saat perancangan peraturan sehingga dapat meminimalisir potensi tumpang tindih.

Permasalahah kekosongan Lembaga yang melakukan harmonisasi terhadap peraturan Menteri direspon oleh Kemenkumham dengan Mmnyusun Peraturan Menteri Hukum dan HAM Nomor 2 Tahun 2019 tentang Penyelesaian Disharmoni Peraturan Perundang-Undangan Melalui Mediasi. Namun, konsep mediasi tersebut menuai banyak kritikan karena dianggap tidak sesuai dengan prinsip hukum publik, mencampur-adukan prinsip privat dan publik, serta tidak konsisten dengan prinsip negara hukum serta peraturan perundang-undangan yang lain. Keberhasilan upaya mediasi yang dilakukan beserta best practicenya ternyata tidak serta merta dapat diadopsi pada objek yang lain. Mediasi lazim diterapkan pada masalah privat. Sedangkan mediasi yang dimaksud Permenkumham Nomor 2 Tahun 2019 terkait dengan kepentingan publik yang merupakan norma hukum sehingga patut untuk dipertanyakan legalitas dan legitimasinya.

Studi ini dapat menjadi bahan masukan dalam melakukan evaluasi terhadap keberadaan peraturan perundang-undangan. Selain itu dapat menjadi pendapat yang mendukung terhadap upaya reformasi regulasi yang tengah dijalankan oleh pemerintah di tengah pesatnya kemajuan. Disadari bahwa hiper regulasi menjadi salah satu masalah di Indonesia yang menyebabkan lambanya pelayanan publik oleh oleh pemerintah kepada warganya.

\footnotetext{
${ }^{5}$ Peraturan Menteri Hukum dan Hak Asasi Manusia Republik Indonesia Nomor 20 Tahun 2015 Tentang Tata Cara dan Prosedur Pengharmonisasian, Pembulatan, dan pemantapan konsepsi rancangan peraturan perundang-undangan

Pasal 2 pengharmonisasian konsepsi rancangan peraturan perundang-undangan dilakukan terhadap:
}

a. Rancangan Undang-Undang;

b. Rancangan Peraturan Pemerintah; dan

c. Rancangan Peraturan Presiden. 


\section{METODE}

Penelitian ini merupakan penelitian hukum normative ditulis dengan susunan: pertama pendahuan yang berisi latar belakang masalah, rumusan, serta tujuan yang ditulis dalam satu bagian yaitu pendahuluan. Kedua metode yang berisi tentang gambaran penelitian yang menjadi pedoman yang mengarahkan penilasan. ketiga adalah pembahasan yang menjawab terkait dengan masalah penelitian. keempat adalah simpulan yang berisi jawaban secara objektif dan padat terkait masalah penelitian. Pengumpulan bahan hukum dilakukan dengan mengidentifikasi peraturan yang terkait seperti peraturan perundang-undangan, putusanan MK, serta literatur yang mendukung. Data yang dikumpulkan kemudian dianalisis dengan mencari kesesuaian dalam pengaturannya. Selain itu, diteliti terkait pengunaan konsep dengan praktek pengaturan tang dituangkan dalam produk hukum. Definisi operasional dari variable yang dimaksud dengan "Peraturan Menteri" adalah peraturan yang ditetapkan oleh menteri berdasarkan materi muatan dalam rangka penyelenggaraan urusan tertentu dalam pemerintahan. Disharmoni Peraturan Perundangundangan yang selanjutnya disebut Disharmoni adalah konflik/pertentangan antar norma hukum atau konflik kewenangan yang timbul karena berlakunya Peraturan Perundang-undangan. Mediasi adalah upaya penyelesaian yang dilakukan di luar pengadilan terhadap disharmoni peraturan perundang-undangan yang dilaksanakan oleh Direktorat Jenderal Peraturan Perundang-undangan, Kementerian Hukum dan Hak Asasi Manusia. Operasional variable dimaksud dengan mendalami terlebih dahulu terkait mediasi beserta implementasinya dalam peraturan perundang-undangan. Setelah memahaminya, dilakukan perbandingan dengan konsep mediasi yang dimaksud dalam Permenkumham Nomor 2 Tahun 2019.

\section{HASIL DAN PEMBAHASAN}

Mempertanyakan Mediasi Sebagai Solusi Disharmoni Peraturan Menteri

Secara teoretis, tata urutan peraturan perundang-undangan dapat dikaitkan dengan ajaran Hans Kelsen mengenai Sfufenbau des Rechtaan The hierarchy of law yang berintikan bahwa kaidah hukum merupakan suatu susunan berjenjang dan setiap kaidah hukum yang lebih rendah bersumber dari kaidah yang lebih tinggi. Untuk lebih memahami teori Stufenbau des Recht, harus dihubungkan dengan ajaran Kelsen yang lain yaitu Reine Rechtslehre atau The pure theory of law (teori murni tentang 
hukum) dan bahwa hukum itu tidak lain "command of the sovereign" kehendak yang berkuasa. ${ }^{6}$

Hukum itu adalah sah (valid) apabila dibuat oleh lembaga atau otoritas yang berwenang membentuknya dan berdasarkan norma yang lebih tinggi sehingga dalam hal ini norma yang lebih rendah (inferior) dapat dibentuk oleh norma yang lebih tinggi (superior), dan hukum itu berjenjang-jenjang dan berlapis-lapis membentuk hierarki, di mana suatu norma yang lebih rendah berlaku, bersumber, dan berdasar pada norma yang lebih tinggi, norma yang lebih tinggi berlaku, bersumber dan berdasar pada norma yang lebih tinggi lagi, demikian seterusnya sampai pada suatu norma yang tidak dapat ditelusuri lebih lanjut dan bersifat hipotetis dan fiktif, yaitu norma dasar (grundnorm). ${ }^{7}$

Hierarki peraturan perundang-undangan di Indonesia tertuang pada pasal 7 UU No. 12 Tahun 2011, diatur pula peraturan perundangundangan lain yang tidak disebutkan dalam hierarki. Ketentuan tersebut tercantum dalam pasal 8 ayat (1). Salah satu yang produk hukum yang diakui adalah Peraturan Menteri yang pada UU No. 10 tahun 2004 tidak dikenal. Peraturan Menteri dapat dibentuk berdasarkan amanat dari peraturan yang lebih tinggi atau berdasarkan kewenangan.

Salah satu masalah dalam pemerintahan saat ini adalah terjadinya hyper regulation. Berdasarlan data yang diperoleh dari laman situs peraturan.go jumlah peraturan dari pusat sampai daerah berjumlah 39294. Peraturan tersebut terdiri atas 3818 peraturan pusat, 15455 Peraturan Menteri, 4041 peraturan LPNK, dan 15982 Peraturan Daerah. ${ }^{8}$ Dari angka tersebut, Peraturan Menteri menyumbangkan sebanyak 15455. Dengan besarnya angka tersebut Peraturan Menteri turut memberi andil terjadinya hiper regulasi. Banyaknya peraturan Menteri salah satu penyebabya adalah adanya ego sektoral yang karena masing-masing kementerial berwenang untuk membentuk Peraturan Menteri. hal tersebut seringkali menimbulkan konflik antar norma.

Melihat prakteknya selama ini, penerapan penyelesaian sengketa melalui mediasi di luar pengadilan sebagaimana dijelaskan di atas dikenal dalam sengketa atau perkara yang bersifat privat, sebagaimana dinyatakan dalam Black's Law Dictionary bahwa mediation is private, informal dispute resolution process in wich a neutral third person, the

\footnotetext{
${ }^{6}$ Bagir Manan, Teori dan Politik Konstitusi, (2004) Cetakan Kedua, FH UII Press, Yogyakarta, him. 201-202.

${ }^{7}$ Ni'imatul Huda, Kedudukan Peraturan Daerah Dalam Hierarki Peraturan PerundangUndangan, (2006) Jurnal Hukum lus Quiea lustum, FH UII, 1 (13) hal 33

${ }^{8}$ Peraturan.go.id
} 
mediator, helps, dispuiting parties to reach an agreement. ${ }^{9}$ Dengan demikian dalam proses mediasi tersebut para pihak bertindak untuk dan atas nama dirinya sendiri sehingga kesepakatan yang dihasilkan berimplikasi secara individu yang kemudian dapat langsung mengikat dan dijalankan oleh para pihak.

Dalam praktiknya, mediasi diimplementasikan dalam beberapa peraturan perundang-undangan antara lain:

Tabel. Peraturan Perundang-Undangan Yang Mengatur Tentang Mediasi

\begin{tabular}{|c|c|c|}
\hline $\begin{array}{l}\text { Peraturan } \\
\text { Perundang- } \\
\text { undangan }\end{array}$ & Pasal & $\begin{array}{c}\text { Ruang } \\
\text { Lingkup }\end{array}$ \\
\hline $\begin{array}{l}\text { UU No. } 48 \\
\text { Tahun } 2009 \\
\text { tentang } \\
\text { Kekuasaan } \\
\text { Kehakiman }\end{array}$ & $\begin{array}{l}\text { Pasal } 58 \\
\text { Upaya penyelesaian sengketa perdata dapat } \\
\text { dilakukan di luar pengadilan negara melalui } \\
\text { arbitrase atau alternatif penyelesaian } \\
\text { sengketa. } \\
\text { Pasal } 60 \\
\text { Alternatif penyelesaian sengketa merupakan } \\
\text { lembaga } \\
\text { penyelesaian sengketa atau beda pendapat } \\
\text { melalui } \\
\text { prosedur yang disepakati para pihak, yakni } \\
\text { penyelesaian } \\
\text { di luar pengadilan dengan cara konsultasi, } \\
\text { negosiasi, } \\
\text { mediasi, konsiliasi, atau penilaian ahli. }\end{array}$ & Privat \\
\hline $\begin{array}{lr}\text { UU No. } & 36 \\
\text { Tahun } & 2009 \\
\text { tentang } & \\
\text { Kesehatan } & \end{array}$ & $\begin{array}{l}\text { Pasal } 29 \\
\text { Dalam hal tenaga kesehatan diduga } \\
\text { melakukan kelalaian dalam menjalankan } \\
\text { profesinya, kelalaian tersebut harus } \\
\text { diselesaikan terlebih dahulu melalui mediasi }\end{array}$ & Privat \\
\hline $\begin{array}{lr}\text { UU No. } & 30 \\
\text { Tahun } & 1999 \\
\text { tentang } & \\
\text { Arbitrase dan } \\
\text { Alternatif }\end{array}$ & $\begin{array}{l}\text { Pasal } 6 \text { ayat (5) } \\
\text { Setelah penunjukan mediator oleh lembaga } \\
\text { arbitrase atau lembaga alternatif } \\
\text { penyelesaian sengketa, dalam waktu paling } \\
\text { lama } 7 \text { (tujuh) hari usaha mediasi harus sudah }\end{array}$ & Privat \\
\hline
\end{tabular}

\footnotetext{
${ }^{9}$ Rachmadi Usman, Pilihan Penyelesaian Sengketa di Luar Pengadilan. (2013). Bandung: PT Citra Aditya Bakti hal, 97.
} 


\begin{tabular}{|c|c|c|}
\hline $\begin{array}{l}\text { Penyelesaian } \\
\text { Sengketa }\end{array}$ & dapat dimulai. & \\
\hline $\begin{array}{lr}\text { UU No. } & 39 \\
\text { Tahun } & 1999 \\
\text { tentang } & \text { Hak } \\
\text { Asasi Manusia }\end{array}$ & $\begin{array}{l}\text { Pasal } 89 \text { ayat (4) } \\
\text { Untuk melaksanakan fungsi Komnas HAM } \\
\text { dalam mediasi sebagaimana dimaksud dalam } \\
\text { Pasal 76, Komnas HAM bertugas dan } \\
\text { berwenang } \\
\text { melakukan: } \\
\text { a. perdamaian kedua belah pihak; } \\
\text { b. penyelesaian perkara melaui cara } \\
\text { konsultasi, negosiasi, mediasi, konsiliasi, dan } \\
\text { penilaian ahli; } \\
\text { c. pemberian saran kepada para pihak untuk } \\
\text { menyelesaikan sengketa melalui pengadilan; } \\
\text { d. penyampaian rekomendasi atas suatu kasus } \\
\text { pelanggaran hak asasi manusia kepada } \\
\text { Pemerintah untuk ditindaklanjuti } \\
\text { penyelesaiannya; dan } \\
\text { e. penyampain rekomendasi atas suatu kasus } \\
\text { pelanggaran hak asasi manusia kepada Dewan } \\
\text { Perwakilan Rakyat Republik Indonesia untuk } \\
\text { ditindaklanjuti. }\end{array}$ & Privat \\
\hline $\begin{array}{lrr}\text { Perma } & \text { No. } & 1 \\
\text { Tahun } & 2016 \\
\text { tentang } & \\
\text { Prosedur } & \\
\text { Mediasi } & \text { di } \\
\text { Pengadilan } & \end{array}$ & $\begin{array}{l}\text { Pasal } 4 \text { ayat (1) } \\
\text { Semua sengketa perdata yang diajukan ke } \\
\text { Pengadilan termasuk perkara perlawanan } \\
\text { (verzet) atas putusan verstek dan perlawanan } \\
\text { pihak berperkara (partij verzet) maupun pihak } \\
\text { ketiga (derden verzet) terhadap pelaksanaan } \\
\text { putusan yang telah berkekuatan hukum tetap, } \\
\text { wajib terlebih dahulu diupayakan } \\
\text { penyelesaian melalui Mediasi, kecuali } \\
\text { ditentukan lain berdasarkan Peraturan } \\
\text { Mahkamah Agung ini }{ }^{10} \text {. }\end{array}$ & Privat \\
\hline
\end{tabular}

Terdapat suatu hal yang berbeda pada implementasi mediasi berdasarkan Permenkumham Nomor 2 Tahun 2019 yang menempatkan mediasi sebagai upaya penyelesaian disharmoni peraturan perundangundangan (Peraturan Menteri). Permenkumham mengadopsi proses mediasi pada Lembaga peradilan, atau pada UU sektoral. Perbedaan yang Nampak pada dua hal tersebut dapat dilihat dari subjeknya, mediasi pada peradilan dilaksanakan karena adanaya sengkete antar individu agar

${ }^{10}$ Muhammad Kamil Akbar, Penyelesaian Konflik Norma Peraturan Perundang Undangan Melalui Jalur Mediasi, 2019, Tesis Magister Hukum, Universitas Indonesia, Jakarta, hal. 90 
tercipta win-win solution, sedangkan pada Permenkumham melakukan mediasi terhadap norma hukum yang berlaku secara umum. Peraturan perundang-undangan pada prinsipnya mengatur umum (orang banyak), peraturan merupakan sebuah kebijakan publik yang dikonkritkan dan diberi dasar hukum dengan peraturan perundang-undangan dengan maksud mengikat secara umum. Peraturan menjadi dasar legitimasi atas Tindakan sepanjang dibentuk oleh organ yang berwenang. Dengan demikian materi muatan dalam peraturan perundang-undangan bukanlah sesuatu yang dapat dinegosiasikan. Terdapat dua kesimpulan yang tegas dalam menilai konflik norma yaitu apakah bertentangan atau sesuai dengan peraturan perundang-undangan lainnya.

Dalam Permenkumham No. 2 Tahun 2019, mekanisme penyelesaian disharmoni peraturan perundang-undangan dilakukan melalui mediasi. Pelaksanaan mediasi dilakukan dengan cara:

a. mendengarkan keterangan Pemohon dan Pihak Terkait;

b. mendengarkan pendapat hukum para Ahli;

c. melakukan klarifikasi kepada Para Pihak; dan

d. menyimpulkan dan membacakan hasil Mediasi. ${ }^{11}$

Adapun hasil dari mediasi penyelesaian disharmoni peraturan perundangundangan tersebut adalah berupa kesepakatan para pihak atau rekomendasi. ${ }^{12}$

Proses mediasi yang dilakukan oleh pemerintah (kementerian hukum dan HAM) patut untuk dievaluasi. Dilihat dari prduk hukum yang dimediasi, merupakan peraturan yang telah disahkan dan berlaku. Pada prinsipnya masing-masing kementerian berwenang untuk membentuk produk hukum sepanjang mendapatkan amanat dari peraturan yang lebih tinggi atau berdasarkan kewenangan. Sulit diterima jika dalam jenjang tugas dan kedudukan yang setara ${ }^{13}$ terdapat Lembaga yang dapat menganulir produk satu sama lain.

Kita telah sepakat bahwa Indonesia adalah negara hukum dengan segala ciri-cirinya (rechstaat). Salah satu ciri dari rechstaat adalah adanya pembagian kekuasaan. Harusnya kita konsisten dengan prinsip tersebut bahwa harus ada Lembaga yang terpisah yang dapat menghakimi produk satu sama lain. tidak boleh ada Lembaga yang sama yang dapat membatalkan produk hukum yang mengatur secara luas berdarkan kewenangan dan amanat peraturan yang lebih tinggi. Sistem hukum di Indonesia telah menyediakan instrumen untuk menyelesaikan sangketa

\footnotetext{
${ }^{11}$ Peraturan Menteri Hukum dan Hak Asasi Manusia tentang Penyelesaian Disharmoni Peraturan Perundang-Undangan MelaluiMediasi, Permenkumham No. 2 Tahun 2019, Berita Negara Republik Indonesia Tahun 2019 Ps. 13 ayat (1).

12 Ibid, Ps. 14.

${ }^{13}$ Berdasarkan UUD Menteri merupakan pembantu presiden.
} 
terkait peraturan perundang-undangan yang diamanatkan kepada Mahkamah Konstitusi (MK) dan Mahkamah Agung (MA).

Masih segar dalam ingatan kita, bahwa MK pernah memutus bahwa kewenangan Menteri Dalam Negeri untuk membatalkan perda yang telah berlaku bertentangan dengan konstitusi. ${ }^{14}$ Salah satu alasan dari MK adalah bahwa pengujian peraturan yang telah berlaku itu masuk daam ranah yudikatif. Hal tersebut konsisten dengan kewenangan yang dimiliki oleh kedua Lembaga peradilan tersebut. Maka dari itu, akan terlahir konsistensi dalam pengaturan perundang-undangan. Dengan adanya putusan Mahkamah Konstitusi Nomor 137/PUU-XIII/2015 dan Putusan Nomor 56/PUU-XIV/2016 yang menyatakan bahwa kewenangan Menteri Dalam Negeri dan Gubernur selaku Wakil Pemerintah Pusat dalam membatalkan Perda Provinsi dan Perda Kabupaten/Kota inkonstitusional atau bertentangan dengan UUD 1945. Maka dalam pengujian terhadap Perda Provinsi dan Perda Kabupaten/Kota hanya MA yang berwenang untuk mengujinya. Kewenangan pemerintah pusat terhadap Perda Provinsi dan Perda Kabupaten/Kota hanya sebatas pengawasan secara preventif yakni pemberlakuan tiap peraturan daerah yang mengatur persoalan-persoalan tertentu, terlebih dahulu mendapatkan pensetujuan dari Menteri Dalam Negeri dan atau Gubernur selaku wakil pemerintah pusat $^{15}$

Guna menjamin konsistensi negara hukum yang salah satunya adalah pemisahan kekuasaan perlu dilakukan evaluasi terhadap praktek yang dijalankan selama ini. Salah satunya adalah tidak mencampur adukan tugas dan wewenang yang secara jelas terpisah berdasarkan amanat peraturan perundang-undangan. Harmonisasi harusnya dapat dilakukan pada saat perancangan peraturan Menteri dengan melibatkan perancang ahli dari kemenkumham. Perancang tersebut dapat menilai potensi peraturan yang disusun bertentangan dengan peraturan yang hierarkinya vertikal maupun horizontal. Dengan penilaian tersebut perancang sejak dari awal dapat menghindarinya atau melakukan mitigasi terhadap resikonya. Pasal 98 ayat (1) mengamatkan bahwa setiap tahapan penyusunan peraturan perundang-undangan harus melibatkan perancang. Namun hal tersebut dihadapkan dengan jumlah sumberdaya manusia perancang dangat terbatas.

\footnotetext{
${ }^{14}$ Putusan tahun 2015

${ }^{15}$ Wahyu Tri Hartomo, Implikasi Putusan Mahkamah Konstitusi Nomor 137/Puu-XIII/2015 Dan Putusan Nomor 56/PUU-XIV/2016 Tentang Pembatalan Perda Provinsi, Perda Kabupaten/Kota, Peraturan Gubernur, Dan Peraturan Bupati/Peraturan Walikota, 2015, Jurnal Legislasi Indonesia, 15 (2). 29-39
} 


\section{PENUTUP}

Terdapat perbedaan yang jelas antara penyelesaian mediasi diatur peraturan perundang-undangan sektoral dengan Permenkumham Nomor 2 Tahun 2019 Tentang Penyelesaian Disharmoni Peraturan PerundangUndangan Melalui Mediasi. Objek mediasi yang berbeda jenis menjadi penyebab masalah, antara peneyelesaian kepentingan privat dan publik. tidak terdapatnya konsistensi dalam pengaturan terkait penyelesian sangketa norma hukum karena keberadaan permenkumham yang menjalankan fungsi eksekutif dengan tugas Lembaga peradilan yang biasa menyelesaikan permaslahan sangketa antar norma. 


\section{DAFTAR PUSTAKA}

\section{Jurnal/Tesis/Disertasi}

Muhammad Kamil Akbar, Penyelesaian Konflik Norma Peraturan

Perundang Undangan Melalui Jalur Mediasi, 2019, Tesis Magister

Hukum, Universitas Indonesia, Jakarta.

Ni'imatul Huda, Kedudukan Peraturan Daerah Dalam Hierarki Peraturan Perundang-Undangan, (2006) Jurnal Hukum lus Quiea lustum, FH UII.

Wahyu Tri Hartomo, Implikasi Putusan Mahkamah Konstitusi Nomor 137/Puu-XIII/2015 Dan Putusan Nomor 56/PUU-XIV/2016 Tentang Pembatalan Perda Provinsi, Perda Kabupaten/Kota, Peraturan Gubernur, Dan Peraturan Bupati/Peraturan Walikota, 2015, Jurnal Legislasi Indonesia, 15 (2).

\section{Peraturan Perundang-Undangan}

Undang-Undang Arbitrase dan Alternatif Penyelesaian Sengketa, UU No. 30 Tahun 1999, LN No. 138 Tahun 1999, TLN No. 3872.

Undang-Undang Kekuasaan Kehakiman, UU No. 48 Tahun 2009, LN No. 157 Tahun 2009, TLN. No. 5076.

Undang-Undang tentang Pembentukan Peraturan Perundang Undangan, UU 12 Tahun 2011, LN Tahun 2011 Nomor 82, TLN Nomor 5234.

Undang-Undang Sistem Peradilan Pidana Anak, UU No. 11 Tahun 2012, LN No. 153 Tahun 2012, TLN No. 5332.

Mahkamah Agung. Peraturan Mahkamah Agung tentang Perosedur Mediasi di Pengadilan, Perma No. 1 Tahun 2016.

Peraturan Menteri Hukum dan Hak Asasi Manusia tentang Penyelesaian Disharmoni Peraturan PerundangUndangan MelaluiMediasi, Permenkumham No. 2 Tahun 2019, Berita Negara Republik Indonesia Tahun 2019.

\section{Buku}

Bagir Manan, Teori dan Politik Konstitusi, (2004) Cetakan Kedua, FH UII Press, Yogyakarta. 
Rachmadi Usman, Pilihan Penyelesaian Sengketa di Luar Pengadilan. (2013). Bandung: PT Citra Aditya Bakti.

\section{Internet}

https:// www.kompas.com/tren/read/2019/10/16/210556065/menelaahfenomena-hiper-regulasi-apa-sebabnya?page=all

https://peraturan.go.id/ 